\title{
Metotreksat kaynaklı beyin hasarına karşı bromelainin potansiyel faydalı etkilerinin araştırılması
}

\author{
Investigation of potential beneficial effects of bromelain against methotrexate- \\ induced brain injury
}

Kürşat Kaya, Ali Gürel, Volkan İpek

\section{Öz}

Amaç: Metotreksat, bazı kanser türleri ve romatoid artrit başta olmak üzere çeşitli hastalıkların tedavisinde kullanılan bir folik asit antagonistidir. Ancak, metotreksat kullanımıyla birlikte görülen ve nörotoksisiteyi de içeren birçok yan etki önemli bir klinik problemdir. Ananas bitkisinden elde edilen bromelain, radikal süpürücü ve lipit peroksidasyonu önleyici etkileri olan enzimatik bir karışımdır.

Gereç ve yöntem: 28 adet sıçan rastgele 4 gruba bölündü $(n=7)$. Birinci grup kontrol grubu olarak tutuldu. İkinci grup BRM grubu olarak belirlendi ve bu gruptaki ratlara 14 gün boyunca $200 \mathrm{mg} / \mathrm{kg} / \mathrm{gün}$ bromelain verildi. Üçüncü grup MTX grubu olarak belirlendi ve bu gruptaki sıçanlara üçüncü gün tek doz $20 \mathrm{mg} / \mathrm{kg}$ metotreksat verildi. Dördüncü grup MTX+BRM grubu olarak belirlendi ve gruptaki sıçanlara metotreksat ve bromelain eşdeğer dozlarda birlikte verildi.

Bulgular: Metotreksat uygulaması gruplar arasında tiyobarbitürik asit reaktif substans seviyeleri açısından herhangi bir değişikliğe neden olmadı ancak redükte glutatyon seviyesinde ve süperoksit dismutaz, glutatyon peroksidaz ve katalaz aktivitelerinde kontrol grubu ile karşılaştırıldığında istatistiksel olarak anlamlı bir azalmaya neden oldu. Metotreksat ile birlikte bromelain uygulanması redükte glutatyon seviyesini ve süperoksit dismutaz aktivitesini metotreksat grubu ile karşılaştırıldığında anlamlı şekilde arttırdı ancak glutatyon peroksidaz ve katalaz aktivitelerindeki artış istatistiki olarak anlamlı değildi. Beyin dokusu histolojik açıdan da değerlendirildi. Metotreksat uygulamasının beyinde histopatolojik olarak belirgin bir lezyon oluşumuna yol açmadığı görüldü. Sonuç: Bulgularımız bromelain kullanımının nörolojik hasara karşı metotreksat ile tedavi edilen hastalarda fayda sağlayabileceğini desteklemektedir.

Anahtar kelimeler: Metotreksat, bromelain, beyin hasarı, oksidatif stres.

Kaya K, Gürel A, İpek V. Metotreksat kaynaklı beyin hasarına karşı bromelainin potansiyel faydalı etkilerinin araştırılması. Pam Tıp Derg 2021;14:846-853.

\footnotetext{
Abstract

Purpose: Methotrexate is a folic acid antagonist used in the treatment of various diseases, especially some types of cancer and rheumatoid arthritis. However, many side effects associated with methotrexate use, including neurotoxicity, are an important clinical problem. Bromelain obtained from the pineapple plant is an enzymatic mixture with radical scavenging and anti-lipid peroxidation effects.

Materials and methods: 28 rats were randomly divided into 4 groups $(n=7)$. The first group was kept as the control group. The second group was determined as the bromelain group and $200 \mathrm{mg} / \mathrm{kg} / \mathrm{day}$ bromelain was given to the rats in this group for 14 days. The third group was determined as methotrexate group and a single dose of $20 \mathrm{mg} / \mathrm{kg}$ methotrexate was given to the rats in this group on the third day. The fourth group was determined as methotrexate + bromelain group, and the rats in the group were given methotrexate and bromelain in equivalent doses together.

Results: Methotrexate administration did not cause any change in thiobarbituric acid reactive levels among groups, but caused a statistically significant decrease in reduced glutathione level and superoxide dismutase, glutathione and catalase activities compared to the control group. The administration of bromelain with methotrexate significantly increased the reduced glutathione level and superoxide dismutase activity compared to the methotrexate group, but the increase in glutathione peroxidase and catalase activities was not statistically significant. Brain tissue was also evaluated histologically. It was observed that methotrexate administration did not cause a significant lesion formation in the brain histopathologically.

Conclusion: Our findings support that the use of bromelain may benefit patients treated with methotrexate against neurological damage.

Kürşat Kaya, Dr. Öğr. Üye. Pamukkale Üniversitesi Tıp Fakültesi, Tıbbi Biyokimya Anabilim Dalı, Denizli, Türkiye, e-posta: kkaya@pau.edu.tr (https://orcid.org/0000-0002-6353-7791) (Sorumlu Yazar)

Ali Gürel, Doç. Dr. Fırat Üniversitesi Tıp Fakültesi, İç Hastalıkları Anabilim Dalı, Nefroloji Bilim Dalı, Elâzığ, Türkiye, e-posta: agurel@firat.edu. $\operatorname{tr}$ (https://orcid.org/0000-0001-8087-8814)

Volkan İpek, Dr. Öğr. Üye. Mehmet Akif Ersoy Üniversitesi Veteriner Fakültesi, Veterinerlik Patolojisi Anabilim Dalı, Burdur, Türkiye, e-posta: volkanipek@mehmetakif.edu.tr (https://orcid.org/0000-0001-5874-7797)
} 
Key words: Methotrexate, bromelain, brain injury, oxidative stress.

Kaya K, Gurel A, Ipek V. Investigation of potential beneficial effects of bromelain against methotrexate-induced brain injury. Pam Med J 2021;14:846-853.

\section{Giriş}

Metotreksat (MTX), kanser tedavisinde ve romatoid artrit, sedefhastalığı ve iltihaplı bağırsak hastalıkları dahil olmak üzere çeşitli otoimmün ve inflamatuar hastalıklarda, gestasyonel trofoblast hastalığının tedavisinde ve ayrıca ektopik gebelikte yaygın olarak kullanılan bir folik asit antagonistidir [1, 2]. Metotreksat hücreye girdikten sonra poliglutamatlanır ve dihidrofolat redüktaz enzimine büyük bir ilgi ile bağlanarak bu enzimin dihidrofolatı tetrahidrofolata dönüştürmesini engeller. DNA sentezi için gerekli olan timidin ve purinlerin biyosentezi için tetrahidrofolat gerektiğinden, MTX tarafından tetrahidrofolat sentezinin bloke edilmesi hücrelerin proteinleri üretememesine sebep olur [3].

Bununla birlikte, MTX tedavisi, doz sınırlamasını ve bazen tedavinin tamamen kesilmesini gerektiren çeşitli ciddi toksik yan etkilere neden olur [4]. MTX kaynaklı toksisitenin mekanizması tam olarak aydınlatılamamışsa da, oksidatif stress, tümör nekrozis faktör alfa ve indüklenebilir nitrik oksit sentaz gibi inflamatuar madiatörlerin salınımı gibi bazı muhtemel mekanizmalar bu toksik etkilerden sorumlu tutulmaktadır [1]. Oksidanlar ve antioksidanlar arasındaki dengesizlikten kaynaklan oksidatif hasar, MTX ile ilişkili doku hasarının ana nedensel faktörlerinden biri olarak değerlendirilmektedir [1]. Metotreksat uygulaması, gastrointestinal toksisite, hepatik toksisite, nefrotoksisite, hematolojik toksisite ve nörotoksisite gibi bir çok doku ve organla ilişkili ciddi toksik etkiler ile ilişkilendirilmektedir [5]. Metotreksat'ın neden olduğu nörotoksisite, akut, subakut veya geç formda meydana gelebilir ve gerek intratekal ve gerekse intravenöz uygulamadan sonra gözlemlenebilir [6].

Ananas comosus (ananas), büyük ölçüde Ekvator bölgelerinde yetiştirilen ve antioksidan, antikanser, antiinflamatuarve anti-plateletfaydalı etkileri ile bilinen bromeliaceae familyasına ait bir bitkidir [7]. Ananas bitkisinin sapından ve meyvesinden elde edilen ve kimyasal olarak 1875 'den beri bilinen bromelain (BRM) ise çeşitli tiol endopeptidazlar ile fosfatazlar, glukozidazlar, peroksidazlar, selülazlar, glikoproteinler, karbonhidratlar ve çeşitli proteaz inhibitörlerinin bir karışımıdır [8]. Biyolojik aktivitesini kaybetmeden bağırsaklardan emilebilen BRM için, trombosit agregasyonunun geri dönüşümlü inhibisyonu, sinüzit, cerrahi travmalar, tromboflebit, piyelonefrit, anjina pektoris ve bronşit gibi çeşitli hastalıklara karşı ve antibiyotikler başta olmak üzere bazı ilaçların emilimini arttırması gibi çok çeşitli terapötik faydaları öne sürülmüştür [8-10]. Bununla birlikte, BRM'in serbest radikal süpürücü ve lipit peroksidasyonu önleyici antioksidan etkileri pek çok çalışmada gösterilmiştir [7, 11, 12].

Tarafımızca yapılan literatür taramasında MTX kaynaklı oksidatif hasara karşı BRM'in etkilerinin araştırıldığı herhangi bir çalışmaya rastlanmamıştır. Bundan dolayı bu çalışmada MTX nedeniyle oluşan oksidatif beyin hasarına karşı BRM'in potansiyel faydalı etkilerinin araştırılması amaçlanmıştır.

\section{Gereç ve yöntem}

\section{Kimyasallar}

MTX (Koçak Farma, 500 mg/20 ml, İstanbul, Türkiye) ve BRM (Solgar, 500 mg, Leonia, New Jersey) eczaneden satın alındı. Kullanılan diğer tüm kimyasallar analitik saflıkta veya mevcut en yüksek saflıktaydı ve Sigma-Aldrich'den satın alındı.

\section{Hayvanlar ve deney dizaynı}

Çalışma için, Adıyaman Üniversitesi Hayvan Deneyleri Yerel Etik Kurulu'ndan etik onayı alınmıştır. Çalışmada Adıyaman Üniversitesi Deney Hayvanları Üretim, Uygulama ve Araştırma Merkezinden temin edilen toplam 28 adet erkek Spraque dawley rat kullanıldı. Polipropilen rat kafeslerine yerleştirilen ratlar çalışma süresince, $21^{\circ} \mathrm{C}$ ortam sıcaklığında ve 12 saatlik aydınlık-karanlık döngüsünde tutuldu. Yem ve su "ad libitum" olarak verildi. 28 adet rat her grupta 7 adet olacak şekilde rastgele 4 gruba bölündü. Birinci gruptaki ratlar kontrol grubu olarak tutuldu ve bu gruptaki ratlara 14 gün boyunca günde 1 kez gavaj ile distile su ve üçüncü gün tek doz serum fizyolojik 
intraperitoneal enjeksiyon ile uygulandı. İkinci grup BRM grubu olarak belirlendi ve bu gruptaki ratlara 14 gün boyunca günde bir kez 200 $\mathrm{mg} / \mathrm{kg}$ dozda BRM gavaj ile verildi ve üçüncü gün tek doz serum fizyolojik enjeksiyonu intra peritoneal enjeksiyon ile uygulandı. Üçüncü grup MTX grubu olarak belirlendi ve bu gruptaki ratlara 14 gün boyunca günde $1 \mathrm{kez}$ gavaj ile distile su ve üçüncü gün tek doz 20 mg/kg MTX intraperitoneal enjeksiyon ile uygulandı. Dördüncü grup MTX+BRM grubu olarak belirlendi ve bu gruptaki ratlara 14 gün boyunca günde 1 kez 200 mg/kg BRM gavaj ile ve üçüncü gün tek doz $20 \mathrm{mg} / \mathrm{kg}$ MTX intraperitoneal enjeksiyon ile uygulandı. Çalışmanın sonunda ksilazin-ketamin kombinasyonu ile anesteziye alınan ratlara eksanguinasyon yöntemi ile ötenazi yapıldı.

Hızlı bir şekilde bütün olarak çıkarılan beyin dokusu soğuk cam üzerinde sagittal düzlemden kesilerek iki yarım beyin küresine ayrıldı. Yarım kürelerden biri histopatolojik inceleme için tespit edildi. Diğer yarım küre biyokimyasal incelemeler yapılıncaya kadar $-86^{\circ} \mathrm{C}$ 'de saklandı.

\section{Biyokimyasal ölçümler}

Dokular 0,2 M Tris-HCl tamponu (pH: 7,4) içerisinde soğuk zincir şartları altında 1:10 (w/v) seyreltme ile homojenize edildi. Tiyobarbitürik asit reaktif substans (TBARS) ölçümleri direk homojenattan yapıldı. Homojenatlar, süperoksit dismutaz (SOD), katalaz (CAT), indirgenmiş glutatyon (GSH) ve glutatyon peroksidaz (GPx) ölçümlerinin yapılması için 3220 rpm'de 30 dk. $\left(4^{\circ} \mathrm{C}\right)$ santrifüj edilerek üstte kalan süpernatan kısımları alındı.

Lipit peroksidasyonunun bir göstergesi olan TBARS seviyeleri Yagi'nin [13] yöntemine göre spektrofotometrik olarak 532 nm'de ölçülerek belirlendi. Sonuçlar nmol/g doku olarak ifade edildi. Hücresel enzimatik antioksidan savunma sistemi üyeleri olan SOD, CAT ve GPx serbest oksijen radikallerine karşı en güçlü savunmayı yapan ilk antioksidan savunma hattı enzimleridir. SOD, süperoksit anyonunu hidrojen peroksite dönüştürerek temizler ve oluşan hidrojen peroksit CAT ve mitokondride GPx tarafından suya dönüştürülerek uzaklaştırılır [14]. SOD, CAT ve GPx aktiviteleri spektrofotometrik yöntemle ölçüldü ve ünite/mg doku proteini olarak gösterildi. SOD aktivitesi Sun ve ark. [15] yöntemine göre 560 nm'de, CAT aktivitesi Aebi
[16] yöntemine göre 240 nm'de ve GPx aktivitesi Paglia ve Valentine'in [17] yöntemine göre 340 nm'de ölçüm yapılarak belirlendi. GSH, serbest radikallere elektron vererek onları nötralize eden ve temizleyen ikinci hat antioksidan savunma sistemi üyelerinden biridir [14]. Beyin dokusu GSH içeriği Sedlak ve Lindsay'ın [18] yöntemine göre belirlendi. GSH düzeyleri 412 nm'de ölçüldü ve nmol/mg doku proteini olarak ifade edildi. Beyin dokusu protein miktarı Lowry metoduna göre belirlendi [19].

\section{Histopatolojik değerlendirme}

Nekropsi sonrası alınan beyin dokuları \%10'luk tamponlu formaldehitte daldırma yöntemi ile tespiti takiben rutin doku takip prosedürlerinden geçirilerek parafine gömüldü ve 5 mikron kalınlığında kesitler alındı. Kesitler hematoksilen-eozin ile boyanarak ışık mikroskobu altında değerlendirildi. Histopatolojik olarak telensefalon, diensefalon, mesensefalon, metensefalon ve myelensefalonda; dejenerasyon, nekroz, kromatoliz, satellitozis, demyelinasyon, myelin solgunluğu, nöropil vakuolizasyonu, aksonal şişkinlik ve sferoid oluşumu, oligodendroglial şişkinlik, intremyelinik ödem, makrofaj infiltrasyonları, gemistositik astrositler ve glial aktivasyon varlığı açısından değerlendirmeler yapıldı.

\section{İstatistik analizler}

İstatistik analizler için IBM SPSS 21 programı (IBM Corporation, Armonk, New York, Amerika Birleşik Devletleri) kullanıldı. Verilerin normallik analizi Shapiro-Wilk testi kullanılarak yapıldı. Gruplar arası farkların önemliliği tek yönlü varyans analizi (ANOVA) testi ile analiz edildi. Post hoc testi olarak, Levene testi sonucunda homojen varyans gösteren veriler için Tukey HSD ve homojen varyans göstermeyen veriler için ise Games-Howell testi kullanıldı. Sonuçlar ortalama sstandart hata (SEM) olarak gösterildi. Güven aralığı \%95 olarak seçildi ve $p<0,05$ düzeyi istatistiksel olarak anlamlı kabul edildi.

\section{Bulgular}

\section{Biyokimyasal bulgular}

Beyin dokusu TBARS ve GSH seviyeleri ile SOD, GPx ve CAT aktiviteleri Tablo 1'de verilmiştir. Çalışmamızda MTX uygulaması TBARS seviyeleri açısından herhangi bir değişikliğe neden olmadı ancak GSH 
Tablo 1. MTX ve BRM uygulanan ratların beyin dokularındaki TBARS ve GSH seviyeleri ile SOD, GPx ve CAT aktivitelerindeki değişiklikler $(n=7)$

\begin{tabular}{llllll}
\hline Gruplar & $\begin{array}{l}\text { TBARS } \\
\text { (nmol/g yaş } \\
\text { doku) }\end{array}$ & $\begin{array}{l}\text { GSH } \\
\text { (nmol/mg doku } \\
\text { prot.) }\end{array}$ & $\begin{array}{l}\text { SOD } \\
\text { (U/mg doku } \\
\text { prot.) }\end{array}$ & $\begin{array}{l}\text { GPX } \\
\text { (U/mg. doku } \\
\text { prot.) }\end{array}$ & $\begin{array}{l}\text { CAT } \\
\text { (U/mg doku } \\
\text { prot.) }\end{array}$ \\
\hline Kontrol & $21,23 \pm 1,63$ & $4,67 \pm 0,10^{\mathrm{a}}$ & $9,40 \pm 0,47^{\mathrm{a}}$ & $1,89 \pm 0,0^{6} \mathrm{a}$ & $20,43 \pm 1,09^{\mathrm{a}}$ \\
BRM & $22,01 \pm 1,15$ & $4,63 \pm 1,82^{\mathrm{ac}}$ & $9,22 \pm 0,48^{\mathrm{ac}}$ & $1,73 \pm 0,14^{\mathrm{ab}}$ & $17,55 \pm 1,46^{\mathrm{ac}}$ \\
MTX & $21,59 \pm 1,04$ & $2,33 \pm 0,50^{\mathrm{bc}}$ & $7,82 \pm 0,31^{\mathrm{bc}}$ & $1,37 \pm 0,01^{\mathrm{b}}$ & $15,22 \pm 1,43^{\mathrm{bc}}$ \\
MTX+BRM & $19,24 \pm 0,79$ & $5,97 \pm 0,64^{\mathrm{a}}$ & $9,41 \pm 0,05^{\mathrm{a}}$ & $1,40 \pm 0,02^{\mathrm{b}}$ & $16,52 \pm 1,09^{\mathrm{ac}}$ \\
\hline
\end{tabular}

Aynı sütun içinde farklı üst simgeler taşıyan ortalamalar istatistiksel olarak anlamlı şekilde farklıdır $(p<0,05)$ Ortalama \pm SEM

seviyesinde ve SOD, GPx ve CAT aktivitelerinde kontrol grubu ile karşılaştırıldığında istatistiksel olarak anlamlı bir azalmaya neden oldu. MTX ile birlikte BRM uygulanması GSH seviyesini ve SOD aktivitesini MTX grubu ile karşılaştırıldığında anlamlı şekilde arttırdı. MTX ile birlikte BRM uygulanması sonucu GPX ve CAT aktivitelerinde de MTX grubuna kıyasla bir miktar artış gözlendi ancak sonuçlar istatistiksel olarak anlamlı değildi. Yalnızca BRM uygulanan ratların sonuçları kontrol grubu ile karşılaştırıldığında herhangi bir anlamlı değişiklik oluşmadığı görüldü.

\section{Histopatolojik bulgular}

Histopatolojik sonuçlar Resim 1-4'te verilmiştir. Histopatolojik değerlendirmelerde daldırma tespiti nedeniyle tüm gruplarda hafif dereceli olarak artefakt ilişkili morfolojik değişikliklere rastlanırken, sözü edilen lezyonlar açısından MTX grubunda kontrol ve BRM grubuna kıyasla belirgin bir morfolojik farklılık gözlenmedi.

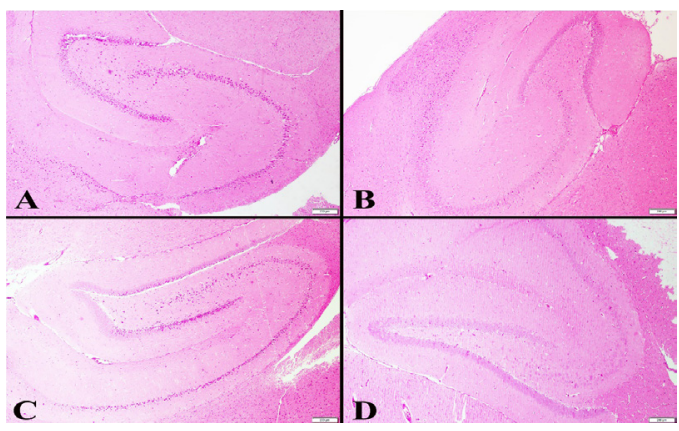

Resim 1. Hipokampüs bölgesinin kontrol (A), BRM (B), MTX (C) ve MTX-BRM (D) gruplarındaki histopatolojik görünümleri. H\&E. Bar: $200 \mu \mathrm{m}$

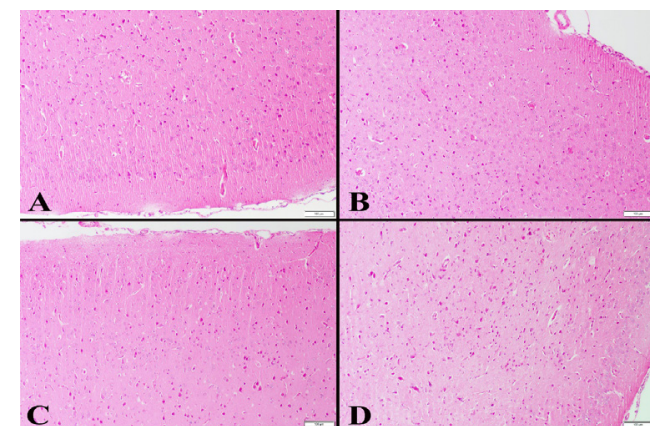

Resim 2. Beyin korteksinin kontrol (A), BRM (B), MTX (C) ve MTX-BRM (D) gruplarındaki histopatolojik görünümleri. H\&E. Bar: $100 \mu \mathrm{m}$

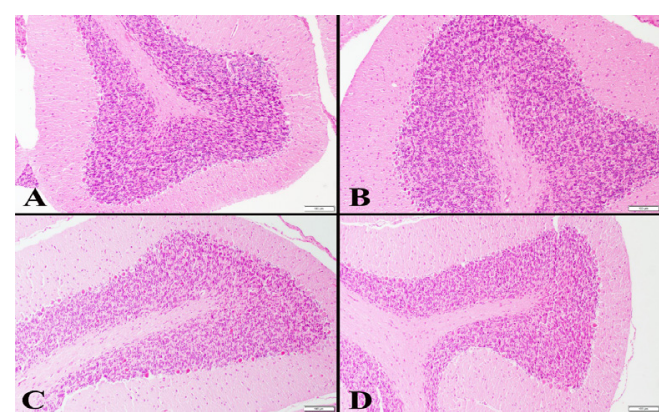

Resim 3. Beyinciğin kontrol (A), BRM (B), MTX (C) ve MTX-BRM (D) gruplarındaki histopatolojik görünümleri. H\&E. Bar: $100 \mu \mathrm{m}$

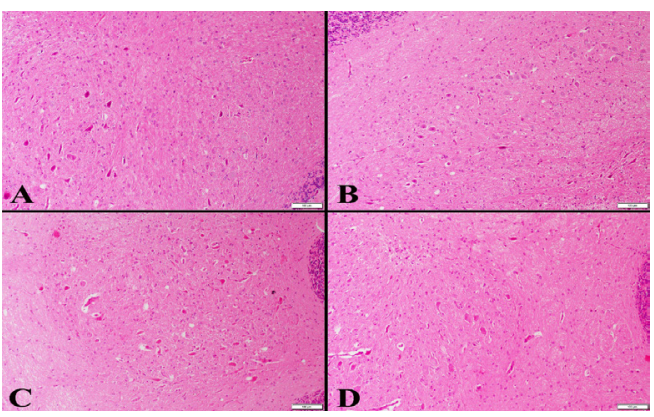

Resim 4. Beyincik ak maddesinin kontrol (A), BRM (B), MTX (C) ve MTX-BRM (D) gruplarındaki histopatolojik görünümleri. H\&E. Bar: $100 \mu \mathrm{m}$ 


\section{Tartışma}

DNA sentezini, onarımını ve hücresel replikasyonu inhibe eden bir antifolat metaboliti olan MTX ilk kez 1951 yılında romatoid artritin ve sedef hastalığının tedavisinde kullanılmıştır [20]. Bugün için lösemi başta olmak üzere birçok malignitede yaygın olarak kullanılan sitotoksik bir kemoterapotik ajandır. Bunun yanında romatoid artrit ve diğer romatizmal hastalıkların tedavisinde kullanılan en yaygın antiromatizmal ilaçtır [21]. MTX, indirgenmiş folat taşıyıcıları ile taşınarak hücreye girer ve hücreye girdikten sonra folil glutamat sentaz enzimi tarafından poliglutamasyona uğratılırarak hücrelerde uzun süre tutulur [20]. MTX poliglutamatlar hücre içinde büyük bir ilgi ile dihidrofolat redüktaz enzimine bağlanır ve dihidrofolatın tetrahidrofolata dönüşmesini engelleyerek timidin ve pürinlerin sentezini ve böylece protein sentezini durdurur [3]. Uzun süreli MTX kullanımı MTX-poliglutamatların hücre içinde birikimine neden olur [22].

MTX'in sitotoksik etkisi sadece kanser hücreleri için seçici değildir ve yüksek proliferasyona sahip kemik iliğinin hematopoietik hücreleri ve bağırsak mukozasının aktif olarak bölünen hücreleri başta olmak üzere çeşitli hücre ve dokuları da etkiler [21]. Bu nedenle, MTX tedavisi sırasında doz sınırlamasını ve bazen tedavinin tamamen kesilmesini gerektiren çeşitli ciddi toksik yan etkiler ortaya çıkabilir [4]. MTX kaynaklı hematopoietik, karsinojenisitik, hepatotoksik, nefrotoksik, pulmoner, gastrointestinal, testikular, kardiyak ve nörotoksik yan etkiler önceki çeşitli çalışmalarda ortaya konulmuştur [20, 22-24].

Nörotoksisite, MTX tedavisi sırasında sıklıkla görülen önemli yan etkilerden biridir. Hem yüksek doz intravenöz MTX hem de intratekal MTX, demiyelinizasyon, beyaz madde nekrozu, oligodendroglia kaybı, aksonal şişme, mikrokistik ensefalomalazi ve derin serebral beyaz madde atrofisi ile ilişkilendirilmiştir [25]. Yüksek doz MTX uygulanan hastaların \%11 kadarında kafa karışıklığı, nöbetler, uyku hali ve radyografik lökoensefalopati kanıtı olan veya olmayan baş ağrıları gibi merkezi sinir sistemi bulguları görülebilir [3]. Akut MTX nörotoksisitesi genellikle afazi, halsizlik, duyu eksiklikleri, ataksi ve nöbetler gibi felç benzeri semptomlarla sonuçlanır [25]. Akut MTX nörotoksisitesi insidansı MTX'in dozuna, uygulama yoluna, verilme sıklığına ve beraberinde folinik asit kullanımına göre değişir [25]. Yang ve ark. [24] meme kanser modeli oluşturulmuş farelere akut MTX uygulamasının zihinsel depresyon ve hafıza kayıplarına neden olduğunu göstermiş ve bu durumu hipokampustaki nörogenezin inhibisyonu ve proinflamatuar enzimlerin artışı ile ilişkilendirmiştir. MTX'in beyin dokusundaki toksisitesinin yeri ve derecesinin belirlenmesi zordur ve manyetik rezonans görüntüleme, elektroensefalografi ve nöropsikolojik testler gibi yardımcı testlerin sonuçları ile klinik belirtiler arasında net bir ilişki gösterilememiştir [6].

MTX, muhtemel merkezi sinir sistemi folat homeostazını bozarak veya doğrudan nöronal hasara yol açarak akut, subakut ve uzun vadeli nörotoksisitelere neden olur [26]. MTX kaynaklı nörotoksisite için çeşitli potansiyel mekanizmalar açıklanmıştır. Bu mekanizmaların en önemlilerinden birinin MTX nedeniyle azalan pürin sentezine bağlı olarak oluşan adenozin birikimi olduğu düşünülmektedir [3]. MTX ve MTX-poliglutamatlar, 5-aminoimidazol-4karboksamid ribonükleotid formiltransferazı inhibe ederek ve adenosin salımını teşvik ederek adenosin yoluna müdahale eder. Adenosin reseptörü polimorfizmleri, MTX ile ilişkili lökoensefalopati ile ilişkilendirilmiştir [5]. MTX ile indüklenen toksisitenin, hücre içi folat homeostazı ve metabolizması için anahtar bir enzim olan metilenetetrahidrofolat redüktaz genindeki mutasyonlarla ilişkili olduğu da varsayılmıştır [4].

MTX kaynaklı doku hasarında ana nedensel faktörlerden birideoksidatifstrestir[1]. MTXhücre içi sitozolik NADPH seviyelerini azaltırken lipit peroksidasyonunu arttırır. NADPH seviyesinin azalması hücreler için önemli bir serbest radikal temizleyici antioksidan olan glutatyon seviyelerinde bir azalmaya yol açar [27]. Ayrıca, MTX, 5-metiltetrahidrofolat seviyesini düşürerek homosistein metabolizmasını bozar ve S-adenozil metiyonin (SAM) seviyesini düşürür. SAM antioksidan etkili bir bileşik olduğundan SAM azalması reaktif oksijen türlerinin artmasına neden olabilir [28]. MTX, oksidatif stres ve DNA hasarına neden olarak çeşitli hipokampal nörojenez tiplerini engeller [29].

Beyin vücut ağırlığının \%2'sinden daha azını oluşturmakta ancak tüm vücudun kullandığı oksijenin \%20'sini tüketmektedir. Bu nedenle 
beyin büyük bir potansiyel oksidatif kapasiteye sahiptir ancak oksidatif strese karşı koyma yeteneği sınırlıdır. Bu durum beyni oksidatif hasara karşı en duyarlı organ haline getirir [30]. Önceki pek çok çalışmada beyin dokusu da dahil çeşitli doku ve organlarda MTX nedeniyle oluşan oksidatif hasar açıkça ortaya konulmuştur. Pınar ve ark. [27] çalışmalarında; tek doz $20 \mathrm{mg} / \mathrm{kg}$ MTX uygulaması hem rat karaciğer ve böbrek dokularında hem de testis dokusunda [23] MDA seviyelerini kontrol grubuna göre anlamlı şekilde arttırmış, SOD, CAT ve GPx aktivitelerini anlamlı şekilde azaltmıştır. Fikry ve ark. [31] çalışmasında MTX uygulaması rat kalp dokusunda MDA seviyesini anlamlı şekilde arttırırken, GSH seviyesinin ve CAT aktivitesinin anlamlı şekilde azalmasına neden olmuştur. Vardi ve ark. [32] MTX uygulanan ratların serebellum dokusunda MDA düzeyinin anlamlı şekilde arttığını ve bununla birlikte GSH seviyesi ile birlikte SOD ve CAT aktivitelerinin anlamlı şekilde azaldığını gözlemlemiştir. Kushwaha ve ark. [33] çalışmasında, 28 gün boyunca farelere 0,5, 1 ve $2 \mathrm{mg} / \mathrm{kg}$ dozlarında oral MTX verilmiş ve hem 1 hem de $2 \mathrm{mg} / \mathrm{kg}$ MTX verilen farelerin beyin dokularında anlamlı şekilde MDA seviyesinde yükselme ve $2 \mathrm{mg} / \mathrm{kg}$ MTX verilen farelerde anlamlı şekilde GSH azalması rapor edilmiştir. Çalışmamızda MTX uygulanması ratların beyin dokusunda TBARS seviyeleri açısından gruplar arasında herhangi bir değişikliğe neden olmadı ancak hem GSH seviyesinde hem de CAT, SOD ve GPx aktivitelerinde kontrol grubu ile karşılaştırıldığında anlamlı şekilde azalma tespit edildi. Bu yönüyle çalışmamızın sonuçları geçmiş çalışmaların sonuçlarıyla büyük oranda uyumluluk gösterdi.

MTX nedeniyle oluşan oksidatif hasarı önlemek amacıyla pek çok anti-oksidan ve anti-inflamatuar madde araştırmacıların ilgisini çekmiş ve pek çok maddenin potansiyel faydalı etkileri çeşitli çalışmalarda araştırılmıştır. Klorojenik asit [32], kafeik asit [28], alfa-lipoik asit [23], tempol [27] ve gallik asit [34] bunlardan bazılarıdır. Tarafımızca yapılan literatür taramasında BRM'in MTX nedeniyle oluşan sinir sistemi toksisitesine karşı potansiyel etkilerinin araştırıldığı herhangi bir çalışmaya rastlanmamıştır. Bu nedenle çalışmamız MTX kaynaklı oksidatif hasara karşı bromelainin potansiyel faydalı etkilerinin araştırıldığı ilk çalışmadır.
BRM, Ananas comosus'tan izole edilen kükürt içeren çeşitli enzimlerin bir karışımıdır. Oral uygulamadan sonra biyolojik aktivitesini kaybetmeden ve bozulmadan emilen ve uzun süreli kullanımda bile yan etkisi bulunmayan BRM, antiinflamatuar, antitrombotik ve antikanser özelliklere sahiptir [35]. Ayrıca BRM'in antioksidan etkileri önceki çeşitli çalışmalarda ortaya konulmuştur. Aliminyum kaynaklı oksidatif hasara karşı 250 mg/g oral BRM uygulaması, El Demerdash ve ark. [7] çalışmasında rat böbrek dokusunda ve Jebur ve ark. [12] çalışmasında rat testis dokusunda TBARS ve $\mathrm{H}_{2} \mathrm{O}_{2}$ seviyelerini anlamlı şekilde azaltmış, bununla birlikte GSH seviyesini ve SOD, CAT ve GPx aktivitelerini anlamlı şekilde arttırarak düzeltmiştir. Agarwal ve ark. [35] diklorvos toksisitesine maruz bırakılmış farelere $70 \mathrm{mg} / \mathrm{kg}$ BRM uygulanmasının serum TBARS ve diğer bir oksidatif stres göstergesi olan protein karbonil içeriği seviyesini anlamlı şekilde azalttığını ve GSH seviyesi ile SOD, CAT ve GPx aktivitelerini yükselttiğini göstermiştir. Çalışmamızda 200 mg/kg oral BRM uygulaması GSH seviyesini ve SOD aktivitesini MTX uygulanan gruba göre istatistiksel olarak anlamlı şekilde arttırdı. GPx ve CAT aktivitelerinde de bir miktar düzelme gözlendi ancak sonuçlar istatistiksel olarak anlamlı değildi. Sonuç olarak BRM uygulanması MTX kaynaklı oksidatif beyin hasarına karşı kısmi olmakla birlikte net bir düzelme sağladı.

MTX'in sinir sistemine olan toksik etkileri histopatolojik olarak da önceki pek çok çalışmada değerlendirilmiştir [2, 32, 36, 37]. Vardi ve ark. [32], çalışmasında MTX uygulamasının ratlarda purkinje hücrelerinin şekillerini kaybedip küçülmesine ve Nissl cisimciklerinin yoğunluğunun azalmasına neden olduğu rapor edilmiştir. Sun ve ark. [2] çalışmasında MTX'in rat fetal beyin dokusunda telensefalik duvar boyunca bol miktarda piknotik nöroepitelyal hücreler oluşturduğu gösterilmiştir. Elens ve ark. [38] çalışmasında $20 \mathrm{mg} / \mathrm{kg}$ MTX enjeksiyonunun dorsal hipokampüste hücre proliferasyonunu baskılamıştır. Çalışmamızda, MTX'in çalışmanın 3. gününde $20 \mathrm{mg} / \mathrm{kg}$ dozda tek sefer intraperitoneal uygulamasının beyinde histopatolojik olarak belirgin bir lezyon oluşumuna yol açmadığı görülmüştür.

Çalışmamızda kullanılan BRM'in saf olarak temin edilememiş olması ve kullanılan tablet 
formda etken maddenin yanında bazı yardımcı maddeler bulunması çalışmamız için bir kısıtııık oluşturmaktadır.

Sonuç olarak, bu çalışmada MTX'in neden olduğu nörooksidatif etki doğrulanmıştır. Ayrıca, MTX ile birlikte uygulanan BRM'in bu toksik etkiyi tersine çevirebilme potansiyeli olduğu gösterilmiştir. Bu nedenle MTX ile tadavi edilen hastalarda oluşabilecek istenmeyen nörolojik yan etkilere karşı BRM kullanımı koruyucu bir tamamlayıcı alternatif olarak değerlendirilebilir.

Çıkar ilişkisi: Yazarlar çıkar ilişkisi olmadığını beyan eder.

\section{Kaynaklar}

1. Hafez HM, Ibrahim MA, Ibrahim SA, Amin EF, Goma W, Abdelrahman AM. Potential protective effect of etanercept and aminoguanidine in methotrexateinduced hepatotoxicity and nephrotoxicity in rats. Eur J Pharmacol 2015;768:1-12. https://doi.org/10.1016/j. ejphar.2015.08.047

2. Sun J, Sugiyama A, Inoue S, Takeuchi T, Furukawa S. Effect of methotrexate on neuroepithelium in the rat fetal brain. J Vet Med Sci 2014;76:347-354. https://doi. org/10.1292/jvms.13-0457

3. Howard SC, McCormick J, Pui CH, Buddington RK, Harvey RD. Preventing and managing toxicities of high-dose methotrexate. Oncologist 2016;21:14711482. https://doi.org/10.1634/theoncologist.2015-0164

4. Campbell JM, Bateman E, Peters MD, Bowen JM, Keefe DM, Stephenson MD. Fluoropyrimidine and platinum toxicity pharmacogenetics: an umbrella review of systematic reviews and meta-analyses. Pharmacogenomics 2016;17:435-451. https://doi. org/10.2217/pgs.15.180

5. Bernsen EC, Hagleitner MM, Kouwenberg TW, Hanff LM. Pharmacogenomics as a tool to limit acute and longterm adverse effects of chemotherapeutics: an update in pediatric oncology. Front Pharmacol 2020;11:1184. https://doi.org/10.3389/fphar.2020.01184

6. Leite RA, Vosgrau JS, Cortez Neto L, et al. Brainstem auditory pathway of children with acute lymphoid leukemia on chemotherapy with methotrexate. Arq Neuropsiquiatr 2020;78:63-69. https://doi. org/10.1590/0004-282X20190139

7. El Demerdash FM, Baghdadi $\mathrm{HH}$, Ghanem NF, Mhanna ABA. Nephroprotective role of bromelain against oxidative injury induced by aluminium in rats. Environ Toxicol Pharmacol 2020;80:103509. https:// doi.org/10.1016/j.etap.2020.103509

8. Pavan R, Jain S, Shraddha, Kumar A. Properties and therapeutic application of bromelain: a review. Biotechnol Res Int 2012;2012:1-6. https://doi. org/10.1155/2012/976203
9. White RR, Crawley FE, Vellini M, Rovati LA. Bioavailability of $125 \mathrm{I}$ bromelain after oral administration to rats. Biopharm Drug Dispos 1988;9:397-403. https:// doi.org/10.1002/bod.2510090408

10. Castell JV, Friedrich G, Kuhn CS, Poppe GE. Intestinal absorption of undegraded proteins in men: presence of bromelain in plasma after oral intake. Am J Physiol 1997;273:139-146. https://doi.org/10.1152/ ajpgi.1997.273.1.G139

11. Ataide JA, De Carvalho NM, Rebelo MDA, et al. Bacterial nanocellulose loaded with bromelain: assessment of antimicrobial, antioxidant and physicalchemical properties. Sci Rep 2017;7:2-10. https://doi. org/10.1038/s41598-017-18271-4

12. Jebur AB, El Demerdash FM, Kang W. Bromelain from Ananas comosus stem attenuates oxidative toxicity and testicular dysfunction caused by aluminum in rats. J Trace Elem Med Biol 2020;62:126631. https://doi. org/10.1016/j.jtemb.2020.126631

13. Yagi K. Simple assay for the level of total lipid peroxides in serum or plasma. Methods Mol Biol 1998;108:101106. https://doi.org/10.1385/0-89603-472-0:101

14. Ighodaro OM, Akinloye OA. First line defence antioxidants-superoxide dismutase (SOD), catalase (CAT) and glutathione peroxidase (GPX): their fundamental role in the entire antioxidant defence grid. Alexandria J Med 2018;54:287-293. https://doi. org/10.1016/j.ajme.2017.09.001

15. Sun Y, Oberley LW, Li Y. A simple method for clinical assay of superoxide dismutase. Clin Chem 1988;34:497-500

16. Aebi H. Catalase. Methods Enzym Anal 1974;673-684.

17. Paglia DE, Valentine WN. Studies on the quantitative and qualitative characterization of erythrocyte glutathione peroxidase. J Lab Clin Med 1967;70:158169.

18. Sedlak J, Lindsay RH. Estimation of total, proteinbound, and nonprotein sulfhydryl groups in tissue with Ellman's reagent. Anal Biochem 1968;25:192-205. https://doi.org/10.1016/0003-2697(68)90092-4

19. Lowry $\mathrm{OH}$, Rosebrough $\mathrm{NJ}$, Farr $\mathrm{AL}$, Randall RJ. Protein measurement with the folin phenol reagent. $\mathrm{J}$ Biol Chem 1951;193:265-275.

20. Wang W, Zhou H, Liu L. Side effects of methotrexate therapy for rheumatoid arthritis: a systematic review. Eur J Med Chem 2018;158:502-516. https://doi. org/10.1016/j.ejmech.2018.09.027

21. Sener G, Ekşioğlu Demiralp E, Çetiner M, Ercan F, Yeğen BC. $\beta$-glucan ameliorates methotrexateinduced oxidative organ injury via its antioxidant and immunomodulatory effects. Eur J Pharmacol 2006;542:170-178. https://doi.org/10.1016/j. 
22. Abdel Daim MM, Khalifa HA, Abushouk Al, Dkhil MA, Al Quraishy SA. Diosmin attenuates methotrexateInduced hepatic, renal, and cardiac Injury: a biochemical and histopathological study in mice. Oxid Med Cell Longev 2017;2017:1-10. https://doi. org/10.1155/2017/3281670

23. Pınar N, Çakırca G, Özgür T, Kaplan M. The protective effects of alpha lipoic acid on methotrexate induced testis injury in rats. Biomed Pharmacother 2018;97:1486-1492. https://doi.org/10.1016/j. biopha.2017.11.078

24. Yang M, Kim JS, Kim J, et al. Acute treatment with methotrexate induces hippocampal dysfunction in a mouse model of breast cancer. Brain Res Bull 2012;89:50-56. https://doi.org/10.1016/j. brainresbull.2012.07.003

25. Rollins N, Winick N, Bash R, Booth T. Acute methotrexate neurotoxicity: findings on diffusionweighted imaging and correlation with clinical outcome. Am J Neuroradiol 2004;25:1688-1695.

26. Bhojwani D, Sabin ND, Pei D, et al. Methotrexateinduced neurotoxicity and leukoencephalopathy in childhood acute lymphoblastic leukemia. J Clin Oncol 2014;32:949-959. https://doi.org/10.1200/ JCO.2013.53.0808

27. Pınar N, Kaplan M, Özgür T, Özcan O. Ameliorating effects of tempol on methotrexate-induced liver injury in rats. Biomed Pharmacother 2018;102:758-764. https://doi.org/10.1016/j.biopha.2018.03.147

28. Uzar E, Koyuncuoglu HR, Uz E, et al. The activities of antioxidant enzymes and the level of malondialdehyde in cerebellum of rats subjected to methotrexate: protective effect of caffeic acid phenethyl ester. Mol Cell Biochem 2006;291:63-68. https://doi.org/10.1007/ s11010-006-9196-5

29. Sirichoat A, Krutsri S, Suwannakot K, et al. Melatonin protects against methotrexate-induced memory deficit and hippocampal neurogenesis impairment in a rat model. Biochem Pharmacol 2019;163:225-233. https:// doi.org/10.1016/j.bcp.2019.02.010

30. Kumar GP, Khanum F. Neuroprotective potential of phytochemicals. Pharmacogn Rev 2012;6:81-90. https://doi.org/10.4103/0973-7847.99898

31. Fikry EM, Hassan WA, Gad AM. Bone marrow and adipose mesenchymal stem cells attenuate cardiac fibrosis induced by methotrexate in rats. J Biochem Mol Toxicol 2017;31:e21970. https://doi.org/10.1002/ jbt.21970

32. Vardi N, Parlakpinar H, Ates B. Beneficial effects of chlorogenic acid on methotrexate-induced cerebellar Purkinje cell damage in rats. J Chem Neuroanat 2012;43:43-47. https://doi.org/10.1016/j. jchemneu.2011.09.003
33. Kushwaha S, Tripathi DN, Vikram A, Ramarao P, Jena GB. Evaluation of multi-organ DNA damage by comet assay from 28 days repeated dose oral toxicity test in mice: a practical approach for test integration in regulatory toxicity testing. Regul Toxicol Pharmacol 2010;58:145-154. https://doi.org/10.1016/j. yrtph.2010.05.004

34. Asci H, Ozmen O, Ellidag HY, Aydin B, Bas E, Yilmaz N. The impact of gallic acid on the methotrexate-induced kidney damage in rats. J Food Drug Anal 2017;25:890897. https://doi.org/10.1016/j.jfda.2017.05.001

35. Agarwal S, Chaudhary B, Bist R. Bacoside a and bromelain relieve dichlorvos induced changes in oxidative responses in mice serum. Chem Biol Interact 2016;254:173-178. https://doi.org/10.1016/j. cbi.2016.05.017

36. Sugiyama A, Sun J, Ueda K, Furukawa S, Takeuchi T. Effect of methotrexate on cerebellar development in infant rats. J Vet Med Sci 2015;77:789-797. https://doi. org/10.1292/jvms.14-0475

37. Hirako A, Furukawa S, Takeuchi T, Sugiyama A. Effect of methotrexate exposure at late gestation on development of telencephalon in rat fetal brain. $\mathrm{J}$ Vet Med Sci 2016;78:213-220. https://doi.org/10.1292/ jvms.15-0389

38. Elens I, Dekeyster E, Moons L, D'Hooge R. Methotrexate affects cerebrospinal fluid folate and tau levels and Induces late cognitive deficits in mice. Neuroscience 2019;404:62-70. https://doi. org/10.1016/j.neuroscience.2019.01.024

Etik kurul onayı: Bu çalışma için, Adıyaman Üniversitesi Hayvan Deneyleri Yerel Etik Kurulu'ndan 04.06.2020 tarih ve 04 sayılı kurul toplantısında 2020/038 protokol numarası ile etik kurul onayı alınmıştır.

\section{Yazarların makaleye olan katkıları}

K.K. çalışmanın ana fikrini ve hipotezini kurgulamıştır. K.K., A.G. ve V.İ. teoriyi geliştirmiş, gereç ve yöntem bölümünü düzenlemişlerdir. K.K. ve A.G. deney hayvanları ile ilgili çalışmayı gerçekleştirmiştir. K.K. biyokimyasal analizleri gerçekleştirmiştir. V.I. histopatolojik incelemeleri gerçekleştirmiştir. Makalenin yazımı K.K. tarafından gerçekleştirilmiştir. A.G. ve V.İ. makaleyi gözden geçirip gerekli düzeltmeleri yapmıştır. Ayrıca tüm yazarlar çalışmanın tamamını tartışmış ve son halini onaylamıştır. 